\title{
Indonesian adaptation of the Revised College Student Subjective Wellbeing Questionnaire
}

\author{
Sari Zakiah Akmal, Dewi Kumalasari, Novika Grasiaswaty \\ Faculty of Psychology, Universitas YARSI, Indonesia \\ Corresponding author: sari.zakiah@gmail.com
}

ARTICLE INFO

Article history

Received December 17, 2020

Revised July 26, 2021

Accepted July 30, 2021

Keywords

college student;

CSSWQ-R;

Indonesian adaptation;

reliability;

validity.

\begin{abstract}
The College Student Subjective Well-being Questionnaire Revised version (CSSWQ-R) was developed to assess university students' domain-specific well-being related to their academic lives. Previous research suggested that the validity and reliability of this scale should be tested in another cultural context. This study aimed to evaluate the psychometric features and structure of the CSSWQ-R in Indonesia. Five hundred eighty-six undergraduate students in Indonesia were recruited as participants with an accidental sampling technique. Confirmatory factor analysis (CFA) was used to determine which of four alternative construct structure models suited best, whether the correlated factor, single factor, $2^{\text {nd }}$ order, or bifactor model. The bifactor model was shown to be the best fit for explaining the structure of the CSSWQ-R Indonesian version, with the total score interpretation being the most meaningful. Further convergent and discriminant validity test was proven, and as expected, this scale related positively with academic resilience and academic achievement (GPA). This research contributes to stimulating research in an educational context concerned with higher education students' subjective well-being.
\end{abstract}

\section{Introduction}

Psychological well-being is a broad construct in positive psychology used across various contexts (e.g., social, educational, health) to describe the healthy and successful human function (Biglan, Flay, Embry, \& Sandler, 2012). Psychological well-being is defined as individual satisfaction with life and the perception of their positive behaviors, such as positive emotions and thoughts (Renshaw, 2016). There are two views on measuring psychological well-being: context-free and domain-specific (Warr, 2012). Context-free well-being measures the broadest scope or the general aspect of life, such as life satisfaction and global happiness. In comparison, domain-specific well-being measures the medium-range focus of life in one segment of an individual's life, such as education, work, family. Both context-free and domain-specific psychological well-being measurements tend to overlap; however, measuring one's well-being in a specific domain is likely more appropriate (Warr, 2012). In different contexts or domains, subjective well-being is affected by various factors; for example, work-related well-being is more responsive to activities and conditions in the employment setting (Zheng, Zhu, Zhao, \& Zhang, 2015).

Given that assumption, Renshaw, Long, \& Cook (2015) modified a context-specific construct of psychological well-being to measure positive psychological state in the school context, and then later for university students (Renshaw \& Bolognino, 2016). This subjective well-being of college students is described as a student's self-assessment of their well-being behavior in the institution's environment (Renshaw, 2018). This construct comprises of four 
main domains: academic satisfaction (an individual's subjective assessment of their academic life's quality), academic efficacy (belief in one's abilities to undertake or complete academic assignments), school connectedness (students' perceptions of pleasant and supportive relationships in university) and college gratitude (the favorable emotional reaction associated with gaining an advantage from university life).

The College Student Subjective Well-being Questionnaire (CSSWQ) is a 15-item self-report scale to assess the four previously mentioned characteristics of college-specific well-being with a higher total score represented higher college student well-being (Renshaw \& Bolognino, 2016). The development and initial validation study of CSSWQ showed that this scale had a single higher-order factor structure. The CSSWQ was a strong predictor of psychological distress and psychological well-being, indicating convergent validity. This scale also demonstrated a high level of internal consistency across components and scales. In its latest revised version (CSSWQ-R), Renshaw (2018) added an item to make it a total of 16-items which were separated evenly into four domains. The revised version had better reliability with factor loading items ranging from .41 to .82 and already had been used to measure college student well-being in other contexts and research (Wilcox \& Nordstokke, 2019; Zhang \& Renshaw, 2020).

Given that the CSSWQ is a promising scale to measure a positive psychological construct specific in an educational context, scholars have been called to test this scale's generalizability in another cultural context (Renshaw \& Arslan, 2016; Renshaw \& Bolognino, 2016). The CSSWQ has been translated into a Turkish version and validated among 548 school-age students of varying economic status (Renshaw \& Arslan, 2016). The Turkish version of the CSSWQ had good psychometric qualities, and construct validity was proven by a significant correlation with self-reported academic achievement and school attitude assessment (Renshaw \& Arslan, 2016). No study has yet been conducted to examine the generalizability of this measure in an Indonesian participant, particularly among college students. Therefore, this research explores the psychometric features and structure of Revised CSSWQ (CSSWQ-R) after it was translated into Indonesian.

\section{Method}

\section{Participants}

These were 586 undergraduate students (74\% female, $26 \%$ male) recruited from the public (39.4\%) and private universities $(59.7 \%)$ in Indonesia, while $.9 \%$ did not report university status. Participants mostly were in their sophomore year $(32.1 \%)$ registered in the various program (e.g., psychology, computer science, dentistry, business, etc.). Participants' age was ranging from $17-23$ years $\left(M_{\text {age }}=20.38\right.$ years, $\left.S D=2.16\right)$. The average of GPA was 3.3 $(S D=.36$, maximum GPA $=4,7.3 \%$ missing $)$. The majority of the participant perceived their socio-economic situation as about the same as their classmates (64.5\%). While the other participants perceived it was as a little worse, as a little better, much worse, and as much better $(20.5 \%, 10.2 \%, 2.9 \%$, and $1 \%$, respectively) with $.9 \%$ missing information.

\section{Materials}

College student well-being. We used the 16-item CSSWQ-R (Renshaw, 2018) translated into Bahasa Indonesian (Akmal, 2018). This scale evaluates the positive experiences students have at university in four domains. It was reported that the Indonesian version of the CSSWQ$\mathrm{R}$ has good discrimination index (corrected item-total correlation $>.30$ ) and good reliability coefficients $(\alpha=.92)$ (Akmal, 2018). The original CSSWQ-R was arranged into a 7-point response Likert scale, from strongly disagree to strongly agree. Previous research showed that Asian respondents tend to choose midpoint Likert-style responses (Lee, Jones, Mineyama, \& Zhang, 2002). Thus, in this current study, we modified the scale format from 7 points to 6 points, from strongly disagree to strongly agree, to minimize the central tendency bias (Bardo, 
Yeager, \& Klingsporn, 1982). Blueprint and Indonesian versions of the CSSWQ-R can be seen in Table 2.

Academic resilience. We used the 30-item Academic Resilience Scale (ARS-30; Cassidy, 2016) translated into Bahasa Indonesian (Kumalasari, Lurhfiyanni, \& Grasiaswaty, 2020). This scale assesses a person's cognitive, affective, and behavioral reactions to help them overcome academic challenges. The ARS-30 is arranged into a 6-point response Likert scale. An example of this is "I would see the situation as a challenge". This Indonesian adaptation reported high internal reliability $(\alpha=.89$; Kumalasari et al., 2020). The alpha Cronbach for this current sample was also .89 .

\section{Procedure}

The Universitas YARSI ethics committee approved this study (ethical clearance number 027/KEP-UY/BIA/I/2021). Researchers contacted the potential participants via their lecturers and the students' social media groups to share the link. This study is voluntary participation; therefore, participants consent before participating in this survey by selecting the "continue" button. Participants have an opportunity to win one of 100 IDR 25.000 electronic vouchers. Therefore, we collected their identity (e.g., phone number and email) only if they want to be participating in the door prize, while those who did not want to enter the draw could skip the personal information parts and submit their responses.

\section{Data analysis}

Confirmatory Factor Analysis

The purpose of this study was to confirm the structure of CSSWQ-R after it was translated into Indonesian. A previous study showed that the CSSWQ-R comprises four correlated dimensions (Renshaw, 2018). Further study also found that the best model fit for the original CSSWQ-R was the bifactor model (Zhang \& Renshaw, 2020). Informed by previous research, then, we assess the bifactor model of the translated version of CSSWQ-R. Bifactor models are applicable when the researcher is interested in exploring the structure of a scale that has both the domain-specific (sub-scale) and the common (general) factors (Chen, West, \& Sousa, 2006).

We used Canivez's (2016) recommendations to evaluate four different models (firstorder, single factor, second-order, and bifactor models) before deciding on the best fit model. First, we assessed the four-correlated model or the first-order model (model A). Each CSSWQ-R item was assigned to a latent variable, and the correlations between the latent variables were calculated. Second, the single-factor model (model B) evaluated whether all of the CSSWQ-R items could be perceived as a single-dimensional scale by assigning all of the items to a single latent variable (general factor). Third, the second-order model (model C) examined if a single or general higher-level factor might represent the four factors. The path from four latent variables to a single or general latent variable is also set in this model. After adjusting for sub-factors, the bifactor model (model D) measured a general factor explaining the common variation. All items were assigned to their respective latent variables as well as a general factor in the bifactor model analysis. Figure 1 visualizes all the models, noting that not all items are illustrated in the figure.

A CFA was conducted to examine the four alternative models (using AMOS V26). For the fit statistic standard, we follow Byrne's (2010) in terms of $\chi^{2}, \chi^{2} / \mathrm{df}$ ratio, the Comparative Fit Index, the Tucker-Lewis Index, the Root Means Square Error Approximation, and the Standardized Root Mean Square Residual. Given that these models were not nested, the Akaike's Information Criterion (AIC) was used to compare fit model, with a lower AIC suggesting a better fit. 


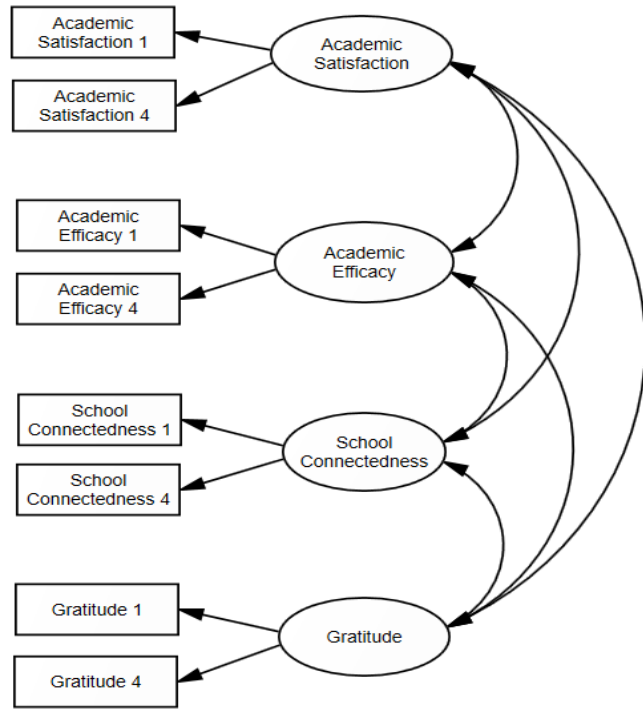

(a) First order factor model

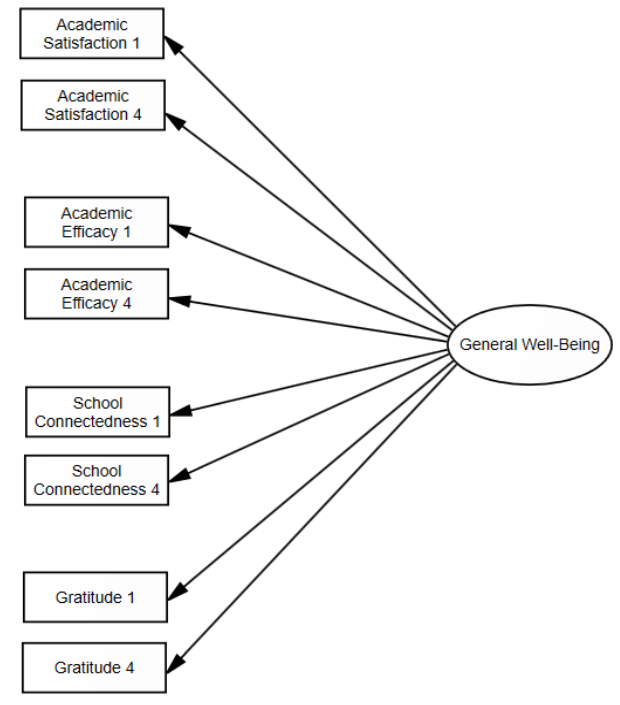

(b) Single factor model

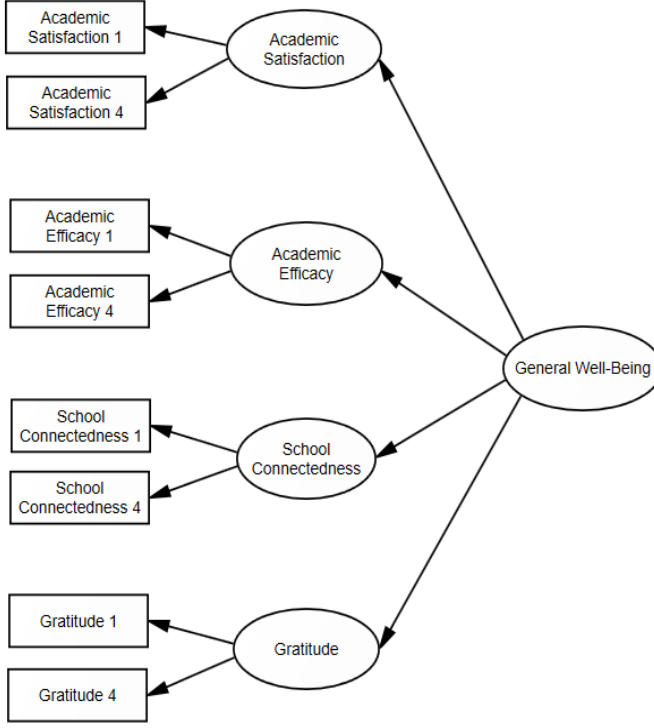

(c) Second order factor model

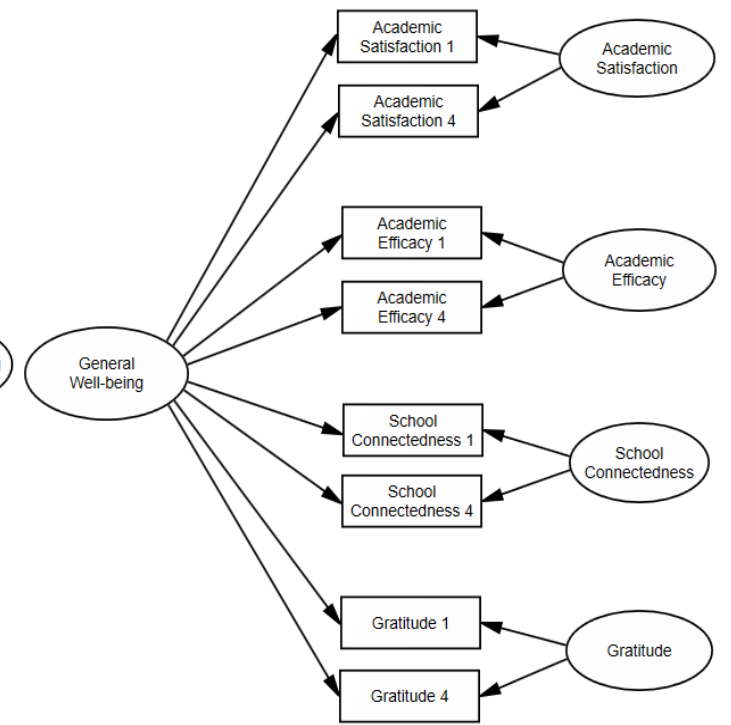

(d) Bifactor model

Figure 1. Confirmatory Factor Analysis Models

If the bifactor model is the most parsimonious, we used Rodriguez, et al. (2016a, 2016b) and Dueber (2017) recommendations to calculate various bifactor model-based psychometric indices factor level, model level, and item level. Since the loading factor varies, we calculated the coefficient omega $(\omega)$ to assess the scale's reliability (Rodriguez et al., 2016b). We also calculate the coefficient hierarchical omega $(\mathrm{omegaH} / \mathrm{H})$ in bifactor structure to estimate the proportion of total scores attributable to a single general factor (Rodriguez et al., 2016b). The relative omega calculates the proportion of the multidimensional composite's reliable variance attributed to a factor. Higher $\mathrm{H}$ for the general factor $(\mathrm{H}>.80)$ and higher relative omega of the general factor (compared to the specific factor) indicates that a construct should be understood at the overall score rather than the subscale level (Rodriguez et al., 2016b).

Explained Common Variance (ECV) is a crucial bifactor statistic used to judge the dimensionality of the common variance in model level analyses (Rodriguez et al., 2016b). The Percent of Uncontaminated Correlations (PUC) was also used to justify with the unidimensional model (Rodriguez et al., 2016a). The scale can be interpreted as 
unidimensional when PUC values are less than.80, general ECV values are larger than.60, and omegaH of the general factor is greater than .70 (Reise, Scheines, Widaman, \& Haviland, 2013). Finally, we estimated the Individual Explained Common Variance (IECV) at the item level, reflecting how representative each item is of the overall component (Stucky \& Edelen, 2015). A higher score (values greater than .80 or .85) indicates an item yields a unidimensional item that is more likely to reflects the general factor (Stucky \& Edelen, 2015).

\section{Construct Validity}

We examined the convergent, discriminant, and nomological validity to assess the CSSWQR Indonesian version's construct validity (Hair, Black, Babin, \& Anderson, 2019).

\section{Convergent and Discriminant Validity}

The degree to which an indicator of a particular construct converges a large proportion of variance in common is measured by convergent validity (Hair et al., 2019). According to Hair et al. (2019), the convergent validity rules of thumb are (a) Average Variance Extracted (AVE) factor loading should be $\geq .50$ and (b) score of Composite Reliability (CR) $\geq .70$ The degree to which a construct is unique from the other constructs is determined by discriminant validity (Hair et al., 2019). Discriminant validity is established if the AVE estimations are more significant than the extracted shared variance (Hair et al., 2019). We used the JASP version (0.14.1) program to run this analysis.

\section{Nomological validity}

The nomological validity test examines whether the correlations between the measurement theory constructs make sense (Hair et al., 2019). We correlated college students' well-being with academic resilience and academic achievement (GPA) to test the nomological validity of CSSWQ-R. Previous studies in the school or college context showed that the well-being scale was significantly associated with students' resilience and general well-being (Aldridge et al., 2016; Harms, Brady, Wood, \& Silard, 2018; Kelifa, Yang, Carly, Bo, \& Wang, 2020). A positive correlation was also found between the well-being and resilience of workers (Kuntz, Näswall, \& Malinen, 2016; McCrea, Walton, \& Leonard, 2016). Moreover, according to a meta-analysis study of 47 research, there was a relatively small to a medium correlation between academic achievement and well-being (Bücker, Nuraydin, Simonsmeier, Schneider, \& Luhmann, 2018). Renshaw \& Chenier (2018) also found a significant positive correlation between student well-being and GPA. Therefore, a significant link between student well-being and academic resilience and achievement was expected to corroborate the CSSWQ-R Indonesian version's construct validity.

\section{Results}

\section{Confirmatory Factor Analysis}

Based on the CFA results (Table 1), only the single-factor model did not represent the CSSWQ-R structure. The bifactor model got the lowest AIC value among the models, indicating that it was the best match to explain the structure of the CSSWQ-R Indonesia version

Table 1

\section{Fit Statistic of Confirmatory Factor Analysis}

\begin{tabular}{lccccccccc}
\hline Model & $\chi^{2}$ & $d f$ & $\chi^{2} / d f$ & TLI & CFI & RMSEA & 90\% CI & SRMR & AIC \\
\hline Model A: $1^{\text {st }}$-order & 368.52 & 97 & 3.80 & .93 & .94 & .07 & {$[.06 ; .08]$} & .05 & 446.52 \\
Model B: Single factor & 1070.27 & 102 & 10.49 & .75 & .79 & .13 & {$[.12 ; .13]$} & .07 & 1138.27 \\
Model C: $2^{\text {nd }}$-order & 384.91 & 99 & 3.89 & .92 & .94 & .07 & {$[.06 ; .08]$} & .05 & 458.91 \\
Model D: Bifactor & 254.05 & 87 & 2.92 & .95 & .96 & .06 & {$[.05 ; .07]$} & .04 & 352.05 \\
\hline
\end{tabular}


The bifactor model also met all the model fit standard in accordance to Byrne (2010), in which, the $\chi^{2} / \mathrm{df}$ ratio $=2.92(<3.00)$, the CFI $=.96(>.90)$, the TLI $=.95(>.90)$, the RMSEA $=.06(<.08)$, and the SRMR $=.04(<.80)$. The Bifactor Indices Calculator (Dueber, 2017) was used to calculate the results of further bifactor model analyses (Table 2).

Table 2

Translated Items and Bifactor Model Coefficients

\begin{tabular}{|c|c|c|c|c|c|c|}
\hline \multirow[t]{2}{*}{ Item } & \multirow[t]{2}{*}{ IECV } & \multicolumn{5}{|c|}{ Standardized Factor Loading } \\
\hline & & General & F 1 & F 2 & F 3 & $\mathrm{~F} 4$ \\
\hline \multicolumn{7}{|l|}{ Academic satisfaction } \\
\hline $\begin{array}{l}\text { Saya memiliki pengalaman akademik yang } \\
\text { menyenangkan di kampus tempat saya berkuliah. }\end{array}$ & .89 & .65 & .23 & & & \\
\hline $\begin{array}{l}\text { Saya merasa senang dengan apa yang sudah saya } \\
\text { peroleh dan lakukan selama menjalani pendidikan di } \\
\text { perguruan tinggi. }\end{array}$ & .50 & .66 & 66 & & & \\
\hline $\begin{array}{l}\text { Saya merasa puas dengan pencapaian akademik saya, } \\
\text { semenjak saya berkuliah di tempat ini. }\end{array}$ & .80 & .57 & 28 & & & \\
\hline $\begin{array}{l}\text { Sejauh ini, saya merasa puas dengan proses belajar } \\
\text { saya di perguruan tinggi. }\end{array}$ & .89 & .58 & .21 & & & \\
\hline \multicolumn{7}{|l|}{ Academic efficacy } \\
\hline $\begin{array}{l}\text { Saya tergolong mahasiswa pekerja keras di kelas } \\
\text { saya. }\end{array}$ & .55 & .58 & & .53 & & \\
\hline Saya adalah mahasiswa yang rajin. & .47 & .61 & & 65 & & \\
\hline $\begin{array}{l}\text { Saya adalah mahasiswa yang dapat mengatur waktu } \\
\text { dan bekerja secara efektif. }\end{array}$ & 69 & .63 & & 42 & & \\
\hline Saya belajar dengan baik di kelas. & .84 & .66 & & .29 & & \\
\hline \multicolumn{7}{|l|}{ School connectedness } \\
\hline $\begin{array}{l}\text { Saya merasa menjadi bagian dari kampus tempat } \\
\text { saya berkuliah saat ini. }\end{array}$ & .98 & .71 & & & .10 & \\
\hline $\begin{array}{l}\text { Orang-orang di kampus ini sangat ramah terhadap } \\
\text { saya. }\end{array}$ & .56 & .54 & & & 48 & \\
\hline $\begin{array}{l}\text { Saya dapat menjadi diri saya sendiri ketika di } \\
\text { kampus. }\end{array}$ & .82 & .66 & & & .31 & \\
\hline $\begin{array}{l}\text { Mahasiswa lain menyukai saya bagaimanapun } \\
\text { keadaan saya. }\end{array}$ & .59 & .57 & & & .49 & \\
\hline \multicolumn{7}{|l|}{ College gratitude } \\
\hline $\begin{array}{l}\text { Saya merasa bersyukur bisa melanjutkan pendidikan } \\
\text { di perguruan tinggi. }\end{array}$ & .16 & .24 & & & & .56 \\
\hline $\begin{array}{l}\text { Saya merasa bersyukur memiliki dosen dan teman } \\
\text { yang bersedia membantu saya. }\end{array}$ & .57 & .61 & & & & .53 \\
\hline $\begin{array}{l}\text { Saya merasa bersyukur memiliki kesempatan untuk } \\
\text { bisa mempelajari hal baru. }\end{array}$ & .34 & .45 & & & & .68 \\
\hline $\begin{array}{l}\text { Saya berterimakasih kepada orang-orang yang sudah } \\
\text { membantu saya untuk dapat berhasil di perguruan } \\
\text { tinggi. }\end{array}$ & .27 & .37 & & & & .62 \\
\hline Explained Common Variance (ECV) & & .60 & 29 & .38 & 27 & 64 \\
\hline Omega $(\Omega)$ & & .93 & .81 & .86 & .81 & .83 \\
\hline Omega $\mathrm{H}(\omega \mathrm{H})$ & & .81 & 19 & .32 & .19 & .55 \\
\hline Relative omega (Relative $\omega$ ) & & .87 & .24 & .37 & .24 & .66 \\
\hline
\end{tabular}

When all items in a factor were taken into account, the proportion of variance explained ( $\omega)$ was .93 (general factor), .81 (academic satisfaction), .86 (academic efficacy), .81 (school connectedness) dan .83 (college gratitude), showing that both the general and subscale factors were highly reliable. The proportion of variance explained by a factor $(\omega \mathrm{H})$ was .81 (general 
factor) and $.19, .32, .19$, and .55 for the respective subscale. It suggests that the Indonesian version of the CSSWQ-R should be interpreted at the total score level rather than the subscale level (Rodriguez et al., 2016b). The proportion of reliable variation owing to a factor (relative $\omega)$ was higher for the general factor (.87) than the subscale $(.24, .37, .24, .66$, respectively), indicating that the total score level interpretation of this scale is more reliable. Furthermore, the PUC was $.80(\leq .80)$, the ECV was $.60(\geq .60)$, and $\omega \mathrm{H}$ for the general factor was .81 (> .70), all of which supported the total score interpretation (Reise et al., 2013). As a result of these findings, the Indonesian version of CSSWQ-R is best used at the total score level. Six items of this scale showed a relatively high IECV $(>.80)$, indicating that those items significantly contributed to the general factor. Those six items are three items of academic satisfaction, one item of academic efficacy, and two school connectedness items. This result suggested that academic satisfaction items mainly explained the variance in college students' well-being (Stucky \& Edelen, 2015).

\section{Construct Validity}

Convergent and Discriminant Validity

We used the AVE and CR in Table 3 to determine the convergent and discriminant validity, as recommended by (Hair et al., 2019).

Table 3

Construct Reliability and Average Variance Extracted Score

\begin{tabular}{llllll}
\hline Indicator & $\lambda$ & s.e & $\lambda^{2}$ & CR & AVE \\
\hline Academic Satisfaction & & & & & \\
AS1 & .23 & .04 & .05 & .92 & .80 \\
AS2 & .66 & .04 & .44 & & \\
AS3 & .28 & .04 & .08 & & \\
AS4 & .21 & .04 & .04 & & \\
Academic Efficacy & & & & .86 & \\
AE1 & .53 & .04 & .28 & & \\
AE2 & .64 & .04 & .42 & & \\
AE3 & .41 & .04 & .17 & & \\
AE4 & .29 & .04 & .08 & & \\
School Connectedness & & & & & \\
SC1 & .10 & .04 & .01 & & \\
SC2 & .48 & .04 & .23 & & \\
SC3 & .31 & .04 & .09 & & \\
SC4 & .49 & .04 & .24 & & \\
College Gratitude & & & & & \\
CG1 & .56 & .02 & .31 & & \\
CG2 & .53 & .03 & .28 & & \\
CG3 & .68 & .03 & .46 & & \\
CG4 & .62 & .02 & .38 & & \\
\hline
\end{tabular}

Table 3 showed that the AVE estimates range from $77 \%$ for school connectedness to $.93 \%$ for college gratitude. All the AVE exceed the 50\% rule of thumbs. The composite Reliabilities (CR) range from .92 for academic satisfaction and school connectedness to .98 for college gratitude; these scores also exceed the minimum score of .70. Based on that analysis, we concluded that the evidence for the convergent validity was supported. The AVE estimations for each factor were then compared to the squared correlations between two factors (Table 4). 
Table 4

Average Variance Extracted and Shared Variance Extracted

\begin{tabular}{lllll}
\hline \multicolumn{1}{c}{ Variable } & 1 & 2 & 3 & 4 \\
\hline 1. Academic satisfaction & .80 & .52 & .46 & .22 \\
2. Academic efficacy & .72 & .86 & .44 & .18 \\
3. School connectedness & .68 & .66 & .77 & .36 \\
4. College gratitude & .47 & .42 & .60 & .93 \\
\hline
\end{tabular}

Table 4 showed that all the AVE estimates (the diagonal) were more significant than the corresponding inter-factor squared correlation estimates (above the diagonal). Therefore, we concluded that the discriminant validity of the CSSWQ-R Indonesia version was proven. In conclusion, CSSWQ-R satisfies both discriminant and convergent validity.

\section{Nomological Validity}

We examined the association between college student well-being and academic resilience and demographic variables to support the nomological validity (Table 5).

Table 5

Construct a Correlation Matrix

\begin{tabular}{|c|c|c|c|c|}
\hline Variables & $M$ & $S D$ & College student well-being & $\begin{array}{l}\text { Academic } \\
\text { resilience }\end{array}$ \\
\hline 1. College student well-being & 75.34 & 9.29 & - & \\
\hline 2. Academic resilience & 138.41 & 16.59 & $.40^{* * *}$ & - \\
\hline 3. GPA & 3.30 & .36 & $.18^{* * *}$ & .07 \\
\hline
\end{tabular}

Note. ${ }^{* * *} \mathrm{p}<.001$.

Table 5 informed that college student well-being is positively related to academic resilience and academic performance. More academic success is measured using their GPA (Bücker et al., 2018; Renshaw \& Chenier, 2018). Therefore, this result supported the nomological validity of the Indonesian version of CSSWQ-R.

In addition, we compare the mean differences in college students' well-being across demographic data (e.g., gender, university, and socio-economic status). There were no significant well-being differences based on participants' gender $(t(546)=0.46, p=.65)$, socio-economic status $(F(4,538)=1.68, p=.15)$, and year of study $(F(5,531)=0.96, p=$ $.44)$. Whereas participants from private universities $(M=76.10, S D=9.25)$ showed a higher well-being than their public's fellows $(M=74.23, S D=9.31 ; t(542)=2.31, p=.021)$.

\section{Discussion}

The bifactor model emerged as the most parsimonious model based on confirmatory factor analysis. This result is consistent with Zhang \& Renshaw's (2020) study. According to bifactor analyses, the 16-item self-report scale assesses four categories of college student well-being, with the interpretation showed most meaningful with the total score. In other words, this scale is more applicable to be interpreting as a total score of college students' well-being. This result strengthened Renshaw's (2018) study, which also indicated that the total score of CSSWQ-R could be accumulated to measure students' subjective well-being during their study at university. Higher total score in CSSWQ-R indicating higher students' subjective well-being related to their academic life.

The current study uses several validity indexes to assess the construct validity, ensuring measurement accuracy. To investigate the convergent and discriminant validity, Hair et al. (2019) suggested computing composite reliability and estimating the average variance. This approach assumes the reflective measurement model that is commonly used in social science. 
Several studies in Indonesia have also used this approach to examine the factor analysis results' construct validity (Ingarianti, Fajrianthi, \& Purwono, 2019; Kumalasari et al., 2020). The convergent and discriminant analysis results revealed the same construct underlies all CSSWQ-R items.

There was a robust positive link between college student satisfaction and academic resilience, as expected $(r=.40, p<.001)$. In line with the previous study, individuals with positive emotions would likely have greater resilience (Kuntz et al., 2016). Positive emotions facilitate individuals' adaptive coping (Folkman \& Moskowitz, 2000), including academic contexts. We also discovered a weak positive link between college satisfaction and academic success. This result is in line with Bücker et al. (2018), and it also indicated that higher student well-being is associated with higher academic achievement or GPA. Further, we found that correlations of this scale with some demographic factors (i.e., gender, age, and SES) were negligible ( $r$ range .02 to .07); indicated that the associations between college student wellbeing and those demographic variables were not significant. These findings corroborated the validity of the scale and revealed no bias in the scale across demographic characteristics.

Different from our expectation, participants from private universities showed higher well-being than their public fellows. We assumed that these score differences were due to external factors rather than bias in these instruments. First, the Indonesian Higher Education System Entrance made segregation among public and private universities (Wicaksono \& Friawan, 2011). Most of the best students in Indonesia are more likely to attend public universities due to better quality and affordable tuition fees than a private university. This condition made competition among students in public universities harder than in private universities. Perceived competition would likely increase anxiety and depression among college students (Posselt \& Lipson, 2016); in turn, it also negatively impacted their wellbeing. Second, a multi-level analysis conducted by Trautwein, Lüdtke, Marsh, \& Nagy (2009) posited that students from high-achiever learning groups tend to have a lower self-concept. Previous studies showed that low self-concept could predict low well-being among students (Hallford \& Mellor, 2016; Hanley \& Garland, 2017). This finding is similar to that of the Mazumder (2014) study, which evaluated student satisfaction at public and private Bangladeshi universities. Based on that previous study, student's expectancy discrepancy in public universities could lead them to feel unsatisfied (Mazumder, 2014). Thus, they tend to have lower college well-being. In conclusion, those previous studies could explain why students in public universities perceived lower well-being than students in private universities in Indonesia.

The CSSWQ-R was translated into Indonesian Bahasa and tested on a group of university students. However, there are significant flaws in this study. First, the sample comprised more female students than males; the majority were second-year students and perceived their socio-economic status as about the same compared to other students. It yields no significant differences in college student well-being across gender, socio-economic status, and year of study. Previous research showed possibilities of invariance among demographic variables (Li, Yang, Ding, \& Kong, 2015). Thus, further research with broader samples needs to examine the possibilities of invariance across another demographic variable.

Second, significant differences between private and public university students also give the insight to consider these characteristics when researching college well-being using this scale. The expected correlations with other related dimensions, academic resilience, and academic accomplishment provided evidence of construct validity of the college student wellbeing Indonesia version. More research is needed to add to the convergent and divergent validity evidence by looking at the relationship with other constructs (i.e., negative correlations with stress; related positively with general life satisfaction). More study is needed to see if this scale has incremental validity when compared to other well-being scales. We also suggest that a future study looks at its social desirability, given all measures measured a positive construct of well-being. 


\section{Conclusion}

In conclusion, the CSSWQ-R Indonesia version shows good psychometric properties. This scale is reliable (general and factors level) and valid to measure college students' subjective well-being. The promising result of this present study enables other researchers in this field to use this instrument confidently. Further bifactor analyses showed that the CSSWQ-R Indonesian version is better interpreted as a general or total student well-being score. This study contributes to stimulating another research in an education context concerned about students' subjective well-being, specific to their college or higher degree education's life.

\section{References}

Akmal, S. Z. (2018). Adaptabilitas karier dan well-being pada mahasiswa tahun pertama (Career adabtability and well-being among first year students). In W. Mangudjaya, N. Effendy, A. R. . Saleh, Rostiana;, \& T. Amir (Eds.). In Positive psychology in dealing with multigeneration (pp. 543-553). HIMPSI.

Aldridge, J. M., Fraser, B. J., Fozdar, F., Ala'i, K., Earnest, J., \& Afari, E. (2016). Students' perceptions of school climate as determinants of wellbeing, resilience and identity. Improving Schools, 19(1), 5-26. https://doi.org/10.1177/1365480215612616

Bardo, J. W., Yeager, S. J., \& Klingsporn, M. J. (1982). Preliminary assessment of formatspecific central tendency and leniency error in summated rating scales. Perceptual and Motor Skills, 54(1), 227-234. https://doi.org/10.2466/pms.1982.54.1.227

Biglan, A., Flay, B. R., Embry, D. D., \& Sandler, I. N. (2012). The critical role of nurturing environments for promoting human well-being. The American Psychologist, 67(4), 257-271. https://doi.org/10.1037/a0026796

Bücker, S., Nuraydin, S., Simonsmeier, B. A., Schneider, M., \& Luhmann, M. (2018). Subjective well-being and academic achievement: A meta-analysis. Journal of Research in Personality, 74, 83-94. https://doi.org/10.1016/j.jrp.2018.02.007

Byrne, B. M. (2010). Structural equation modeling with AMOS: Basic concepts, applications, and programming (2nd ed.). Routledge/Taylor \& Francis Group.

Canivez, G. L. (2016). Bifactor modeling in construct validation of multifactored tests: Implications for understanding multidimensional constructs and test interpretation. In K. Schweizer \& C. DiStefano (Eds.). Principles and methods of test construction: Standards and recent advances (pp. 247-271). Hogrefe Publishing.

Cassidy, S. (2016). The Academic Resilience Scale (ARS-30): A new multidimensional $\begin{array}{lllll}\text { construct measure. Frontiers in Psychology, } & 1787 .\end{array}$ https://doi.org/10.3389/fpsyg.2016.01787

Chen, F. F., West, S. G., \& Sousa, K. H. (2006). A comparison of bifactor and second-order models of quality of life. Multivariate Behavioral Research, 41(2), 189-225. https://doi.org/10.1207/s15327906mbr4102_5

Dueber, D. M. (2017). Bifactor indices calculator: A Microsoft excel-based tool to calculate various indices relevant to bifactor CFA models. https://doi.org/10.13023/edp.tool.01

Folkman, S., \& Moskowitz, J. T. (2000). Positive affect and the other side of coping. American Psychologist, 55(6), 647-654. https://doi.org/10.1037/0003-066X.55.6.647

Hair, J. F., Black, W. C., Babin, B. J., \& Anderson, R. E. (2019). Multivariate Data Analysis (8th ed.). Cengage Learning.

Hallford, D. J., \& Mellor, D. (2016). Brief reminiscence activities improve state well-being and self-concept in young adults: A randomised controlled experiment. Memory, 


\section{4(10), 1311-1320. https://doi.org/10.1080/09658211.2015.1103875}

Hanley, A. W., \& Garland, E. L. (2017). Clarity of mind: Structural equation modeling of associations between dispositional mindfulness, self-concept clarity and psychological well-being. Personality and Individual Differences, 106, 334-339. https://doi.org/10.1016/j.paid.2016.10.028

Harms, P. D., Brady, L., Wood, D., \& Silard, A. (2018). Resilience and well-being. In E. Diener, S. Oishi, \& L. Tay (Eds.). Handbook of well-being. DEF Publishers.

Ingarianti, T. M., Fajrianthi, \& Purwono, U. (2019). Adaptasi instrumen komitmen karier (Adaptation of career commitment intrument). Jurnal Psikologi, 18(2), 199-217.

Kelifa, M. O., Yang, Y., Carly, H., Bo, W., \& Wang, P. (2020). How adverse childhood experiences relate to subjective wellbeing in college students: The role of resilience and depression. Journal of Happiness Studies, 22(2103-2123). https://doi.org/10.1007/s10902-020-00308-7

Kumalasari, D., Lurhfiyanni, N. A., \& Grasiaswaty. (2020). Analisis faktor adaptasi instrumen resiliensi akademik versi Indonesia: Pendekatan eksploratori dan konformatori (Factor analysis of adaptation Indonesian version academic resilience instrument: Exploratory and confirmatory approaches). Jurnal Penelitian Dan Pengukuran Psikologi, 9(2), 84-95. https://doi.org/10.21009/JPPP.092.06

Kuntz, J. R. C., Näswall, K., \& Malinen, S. (2016). Resilient employees in resilient organizations: Flourishing beyond adversity. Industrial and Organizational Psychology: Perspectives on Science and Practice, 9(2), 456-462. https://doi.org/10.1017/iop.2016.39

Lee, J. W., Jones, P. S., Mineyama, Y., \& Zhang, X. E. (2002). Cultural differences in responses to a Likert scale. Research in Nursing and Health, 25(4), 295-306. https://doi.org/10.1002/nur.10041

Li, M., Yang, D., Ding, C., \& Kong, F. (2015). Validation of the Social Well-being Scale in a Chinese sample and invariance across gender. Social Indicators Research, 121(2), 607-618. https://doi.org/10.1007/s11205-014-0639-1

Mazumder, Q. H. (2014). Analysis of quality in public and private universities in Bangladesh and USA. International Journal of Evaluation and Research in Education (IJERE), 3(2), 99-108. https://doi.org/10.11591/ijere.v3i2.2886

McCrea, R., Walton, A. M., \& Leonard, R. (2016). Developing a model of community wellbeing and resilience in response to change. Social Indicators Research, 129(1), 195-214. https://doi.org/10.1007/s11205-015-1099-y

Posselt, J. R., \& Lipson, S. (2016). Competition, anxiety, and depression in the college classroom: Variations by student identity and field of study. Journal of College Student Development, 57(8), 973-989. https://doi.org/10.1353/csd.2016.0094

Reise, S. P., Scheines, R., Widaman, K. F., \& Haviland, M. G. (2013). Multidimensionality and structural coefficient bias in structural equation modeling: A bifactor perspective. Educational and Psychological Measurement, 73(1), 5-26. https://doi.org/10.1177/0013164412449831

Renshaw, T. L. (2016). Psychometric properties of the Social and Emotional Health Survey with a small sample of academically at-risk adolescents. Journal of Psychoeducational Assessment, 34(5), 487-495. https://doi.org/10.1177/0734282915614495

Renshaw, T. L. (2018). Psychometrics of the Revised College Student Subjective Wellbeing Questionnaire. Journal of School Psychology, 33(2), 136-149. https://doi.org/10.1177/0829573516678704

Renshaw, T. L., \& Arslan, G. (2016). Psychometric properties of the Student Subjective Wellbeing Questionnaire with Turkish adolescents: A generalizability study. Canadian 
Journal of School Psychology, 31(2), 139-151. https://doi.org/10.1177/0829573516634644

Renshaw, T. L., \& Bolognino, S. J. (2016). The College Student Subjective Wellbeing Questionnaire: A brief, multidimensional measure of undergraduate's covitality. Journal of Happiness Studies, 17(2), 463-484. https://doi.org/10.1007/s10902-0149606-4

Renshaw, T. L., \& Chenier, J. S. (2018). Further validation of the Student Subjective Wellbeing Questionnaire: Comparing first-order and second-order factor effects on actual school outcomes. Journal of Psychoeducational Assessment, 36(4), 392-397. https://doi.org/10.1177/0734282916678494

Renshaw, T. L., Long, A. C. J., \& Cook, C. R. (2015). Assessing adolescents' positive psychological functioning at school: Development and validation of the Student Subjective Wellbeing Questionnaire. School Psychology Quarterly, 30(4), 534-552. https://doi.org/10.1037/spq0000088

Rodriguez, A., Reise, S. P., \& Haviland, M. G. (2016a). Applying bifactor statistical indices in the evaluation of psychological measures. Journal of Personality Assessment, 98(3), 223-237. https://doi.org/10.1080/00223891.2015.1089249

Rodriguez, A., Reise, S. P., \& Haviland, M. G. (2016b). Evaluating bifactor models: Calculating and interpreting statistical indices. Psychological Methods, 21(2), 137-150. https://doi.org/10.1037/met0000045

Stucky, B. D., \& Edelen, M. O. (2015). Using hierarchical IRT models to create unidimensional measures from multidimensional data. In S. P. Reise \& D. A. Revicki (Eds.). Handbook of item response theory modeling: Applications to typical performance assessment (pp. 183-206). Routledge/Taylor \& Francis Group.

Trautwein, U., Lüdtke, O., Marsh, H. W., \& Nagy, G. (2009). Within-school social comparison: How students perceive the standing of their class predicts academic selfconcept. Journal of Educational Psychology, 101(4), 853-866. https://doi.org/10.1037/a0016306

Warr, P. (2012). How to think about and measure psychological well-being. In Sinclair, R.R., Wang, M., \& Tetrick, L.E. (Eds.). In Research methods in occupational health psychology: Measurement, design and data analysis. https://doi.org/10.4324/9780203095249

Wicaksono, T. Y., \& Friawan, D. (2011). Recent developments in higher education in Indonesia: Issues and challenges. In S. Armstrong \& B. J. Chapman (Eds.). Financing higher education and economic development in East Asia (pp. 159-170). ANU E Press.

Wilcox, G., \& Nordstokke, D. (2019). Predictors of university student satisfaction with life, academic self-efficacy, and achievement in the first year. Canadian Journal of Higher Education, 49(1), 104-124. https://doi.org/10.7202/1060826ar

Zhang, D. C., \& Renshaw, T. L. (2020). Personality and college student subjective wellbeing: A domain-specific approach. Journal of Happiness Studies, 21(3), 9971014. https://doi.org/10.1007/s10902-019-00116-8

Zheng, X., Zhu, W., Zhao, H., \& Zhang, C. H. I. (2015). Employee well-being in organizations: Theoretical model, scale development, and cross-cultural validation. Journal of Organizational Behavior, 36(5), 621-644. https://doi.org/10.1002/job.1990 